\title{
Faktor yang Berhubungan dengan Indeks Populasi Lalat pada Tempat Penampungan Sementara (TPS) Sampah di Pasar Kota Malang dan Kota Batu
}

\author{
Muhammad Al-Irsyad*, Ema Novita Deniati \\ Universitas Negeri Malang, Jl. Semarang No. 5 Malang, Jawa Timur, Indonesia \\ *Penulis korespondensi, Surel: muhammad.irsyad.fik@um.ac.id
}

Paper received: 24-5-2021; revised: 14-6-2021; accepted:21-6-2021

\begin{abstract}
The temporary shelter of garbage in the market is an ideal location for the life of flies. The temperature and humidity of the air in the temporary shelters support the increasing fly population in the market. The increasing population of flies is feared to contaminate food and drinks sold in the market. This is because flies are mechanical vectors for various pathogenic microorganisms that can endanger human health. This study uses a survey method with a cross-sectional approach. Temperature and humidity were measured using an android-based application, while the fly population was measured using a flygrill. The data were analyzed using the Pearson Correlation test to see the correlation between the average temperature and average humidity with the fly population index. The results of this study indicate that there is no correlation between the average temperature and the fly population index. There is a correlation between the average humidity in the afternoon and the Flies Population Index in the morning. The correlation between the two is a strong negative.
\end{abstract}

Keywords: fly population index; garbage temporary shelter; market trash

\begin{abstract}
Abstrak
Tempat penampungan sementara sampah pasar merupakan lokasi yang ideal bagi kehidupan lalat. Suhu dan kelembaban udara yang ada di tempat penampungan sementara mendukung meningkatnya populasi lalat di pasar. Meningkatnya populasi lalat dikhawatirkan akan mengkontaminasi makanan dan minuman yang dijual di pasar. Hal tersebut dikarenakan lalat merupakan vektor mekanik bagi berbagai mikroorganisme patogen yang dapat membahayakan kesehatan manusia. Penelitian ini menggunakan metode survei dengan pendekatan cross Sectional. Suhu dan kelembaban diukur dengan menggunakan aplikasi berbasis android, sedangkan populasi lalat diukur dengan menggunakan fly grill. Data dianalisis dengan uji Pearson Correlation untuk melihat korelasi antara suhu rata-rata dan kelembaban rata-rata dengan indeks populasi lalat. Hasil penelitian ini menunjukan tidak terdapat korelasi suhu rata-rata dengan indeks populasi lalat. Terdapat korelasi antara kelembaban rata-rata pada waktu sore hari dengan Indeks Populasi Lalat pada waktu pagi hari. Hubungan korelasi di antara keduanya bersifat negatif kuat.
\end{abstract}

Kata kunci: indeks populasi lalat; tempat penampungan sementara; sampah pasar

\section{Pendahuluan}

Lalat merupakan serangga yang kerap ditemukan di lingkungan dan dapat menyebabkan berbagai masalah bagi kesehatan manusia. Serangga ini merupakan salah satu vektor penyakit yang dapat menyebabkan vector-borne diseases maupun food-borne diseases. Lalat merupakan penular untuk berbagai macam penyakit pada manusia, seperti diare, myasis, kecacingan dan antraks (Andiarsa, 2018). Sedangkan menurut Iqbal et al. (2014), lalat dapat berperan sebagai agen penularan berbagai penyakit, tidak hanya pada manusia, namun juga pada unggas dan ternak. Penyakit-penyakit pada manusia antara lain tipus, disentri, difteri, kusta, TBC dan parasit usus. Sedangkan penyakit yang berhubungan dengan unggas dan ternak 
seperti kolera unggas dan antraks. Selain itu, lalat juga merupakan vektor dan hospes perantara nematoda pada kuda dan beberapa cestoda pada unggas.

Pasar merupakan lokasi yang ideal untuk perkembangbiakan lalat, sehingga lalat kerap ditemukan di pasar-pasar. Menurut Poluakan, Rumajar, \& Pakasi (2016), pasar yang tidak diperhatikan kebersihan dan kesehatannya seperti pembuangan sampah maupun pengelolaan limbah, sangat potensial bagi perkembangbiakan lalat. Dan lalat merupakan salah satu indikator dari kebersihan pasar. Hasil penelitian Yunus \& Juherah (2020) di Pasar Tradisional Kota Makassar menemukan masalah penanganan sampah yang kurang efektif, dan di saat yang sama rata-rata kepadatan lalat di pasar tersebut tidak memenuhi baku mutu vektor lalat. Penelitian lain di Pasar Desa Adat Sembung mengungkapkan, bahwa tingkat kepadatan lalat dari 48 kali pengukuran, sebanyak 56,3\% mendapatkan hasil kepadatan lalat yang tinggi. Hal tersebut diakibatkan oleh sampah yang berserakan di sekitar kios pedagang, pedagang makanan, penjual buah, sayur dan daging, serta sisa makanan yang berbau busuk sehingga mengundang lalat untuk hinggap dan berkembang biak (Ayu, Sali, \& Aryana, 2020).

Menurut Andiarsa (2018), lalat terbukti kuat sebagai vektor mekanik penyebaran berbagai mikroorganisme patogen. Kemampuan lalat untuk terbang dan hinggap di berbagai permukaan, memudahkan lalat mengkontaminasi makanan dan minuman. Lalat mengambil berbagai organisme patogen dari sampah, limbah dan berbagai sumber kotoran lainnya, dan kemudian dipindahkan melalui mulut, muntahan, feces, dan tubuhnya yang telah terkontaminasi ke makanan manusia dan hewan (Sanchez-Arroyo \& Capinera, 2013). Hal tersebut terbukti dengan ditemukannya berbagai macam parasit, jamur, hingga virus di tubuh lalat. Organisme patogen tersebut antara lain adalah Ascaris spp. Entamoeba spp., cacing tambang, Trichuris spp., Penicillium spp., Aspergillus spp., dan Candida spp. (Khamesipour, Lankarani, Honarvar, \& Kwenti, 2018).

Salah satu lokasi yang ideal bagi perkembangbiakan lalat di pasar ialah Tempat Penampungan Sementara (TPS) sampah. Banyaknya sampah dan sisa makanan yang dibuang menjadikan lalat dengan mudah berkembang biak di tempat tersebut. Hal tersebut terbukti dengan hasil pengukuran kepadatan lalat di TPS sampah Pasar Motoling yang menemukan tingkat kepadatan yang tinggi dengan rata-rata kepadatan 18 ekor/blok grill (Poluakan et al., 2016). Penelitian Rahmadana \& Taha (2020), menemukan tingkat kepadatan lalat yang tinggi sebesar 10 ekor/blok grill di TPS Tempat Pelelangan Ikan. Keberadaan vektor lalat di TPS pasar salah satunya diakibatkan oleh pengelolaan sampah pasar yang buruk. Sebuah studi literatur menyatakan bahwa sekitar 50\% keberadaan lalat rumah (Musca domestica) di perkotaan dikarenakan pengelolaan limbah rumah tangga, rumah sakit dan pasar yang buruk (Iqbal et al., 2014).

Kondisi lingkungan berpengaruh terhadap kepadatan lalat di suatu lokasi. Lalat membutuhkan kondisi lingkungan yang optimum untuk hidup dan berkembang biak. Sejauh ini, hasil penelitian menunjukan bahwa suhu udara berpengaruh sangat nyata terhadap setiap fase kehidupan lalat mulai dari telur hingga menjadi lalat dewasa (Ihsan, Hidayati, \& Hadi, 2016). Hasil penelitian lainnya menunjukan bahwa tidak terdapat hubungan signifikan antara kelembaban dengan kepadatan lalat pada rumah penduduk di Desa Purwodadi (Ramadhani, Hestiningsih, \& Kusariana, 2019). Begitupun hasil temuan dari Afrilia \& Wispriyono (2017), yang menyatakan tidak terdapat hubungan yang signifikan antara suhu dengan kepadatan lalat 
di rumah sekitar Tempat Pembuangan Akhir (TPA) sampah. Oleh karena itu, penelitian untuk melihat hubungan suhu dengan kepadatan lalat masih cukup relevan untuk dilakukan.

Selain suhu faktor lingkungan lainnya yang mempengaruhi kepadatan populasi lalat ialah kelembaban udara. Sejauh ini masih sedikit bukti yang menunjukan hubungan kelembaban dengan kepadatan lalat sehingga masih sangat terbuka ruang untuk diteliti lebih jauh. Penelitian-penelitian yang ada terbatas hanya mengukur kelembaban udara dengan kepadatan lalat, tetapi tidak dijelaskan lebih lanjut apakah kelembaban udara berpengaruh terhadap kepadatan lalat. Dari sedikit temuan tersebut, hasil pengukuran di rumah sekitar Tempat Pembuangan Akhir (TPA) sampah menunjukkan bahwa tidak terdapat hubungan yang signifikan antara kelembaban dengan kepadatan lalat di dalam dan di luar rumah. Akan tetapi, hasil uji statistik justru menunjukkan bahwa kelembaban yang optimum berisiko 2,2 kali memiliki kepadatan lalat yang tinggi di dalam rumah dibandingkan dengan kelembaban rumah yang tidak optimum (Afrilia \& Wispriyono, 2017).

Berdasarkan uraian latar belakang diatas, penelitian ini bertujuan untuk mengukur tingkat kepadatan kepadatan lalat di Tempat Penampungan Sementara (TPS) sampah pada pasar di Kota Malang dan Kota Batu, dan faktor-faktor yang mempengaruhinya. Penelitian ini penting untuk dilakukan mengingat sejauh ini masih sulit ditemukan penelitian terkait dengan kepadatan lalat yang dilakukan di Kota Malang ataupun Kota Batu. Selain itu, masih minimnya penelitian yang meneliti hubungan antara suhu dan kelembaban dengan kepadatan lalat di TPS sampah pasar, menjadikan penelitian ini penting untuk dilakukan.

\section{Metode}

Penelitian ini menggunakan metode survey dengan pendekatan cross Sectional, yang mana penelitian dilakukan pada satu waktu. Pengumpulan data dilaksanakan pada bulan April 2021 di Pasar Besar Kota Batu dan Pasar Krempyeng, Lawang, serta Niwen Bakalankrajan Kota Malang.

Pengukuran suhu dan kelembaban dilakukan dengan menggunakan aplikasi pengukur suhu dan kelembaban berbasis android. Pengukuran dilaksanakan pada pagi hari pukul 07.0009.00, siang hari 12.00-13.00, dan sore hari pukul 16.00-17.00. Masing-masing pengukuran dilakukan sebanyak 5 kali, kemudian dirata-ratakan.

Pengukuran kepadatan lalat dilakukan dengan menggunakan fly grill yang diletakan di sekitar Tempat Penampungan Sementara (TPS) sampah. Pengukuran dilaksanakan pada pagi hari pukul 07.00-09.00, siang hari 12.00-13.00, dan sore hari pukul 16.00-17.00. Perhitungan kepadatan dilakukan dengan berdasarkan panduan survei kepadatan lalat dari Kementerian Kesehatan (2017). Kepadatan dihitung dengan melakukan pengamatan selama 30 detik dan pengulangan sebanyak 10 kali untuk setiap titik pengamatan. Dari 10 kali pengamatan diambil 5 (lima) nilai tertinggi, kemudian dirata-ratakan.

Hasil pengukuran kemudian dianalisis dengan uji product moment correlation atau yang biasa dikenal dengan istilah Pearson Correlation. Uji ini dilakukan untuk melihat korelasi antara suhu rata-rata dengan indeks populasi lalat dan kelembaban rata-rata dengan indeks populasi lalat. 


\section{Hasil dan Pembahasan}

\subsection{Suhu}

Hasil pengukuran suhu rata-rata yang dilakukan pada pagi, siang dan sore hari di Tempat Penampungan Sementara (TPS) sampah Pasar Besar Kota Batu, Pasar Krempyeng, Pasar Lawang, dan Pasar Niwen Bakalankrajan, disajikan pada tabel 1.

Tabel 1. Suhu Rata-Rata di Tempat Penampungan Sementara (TPS)

\begin{tabular}{lccc}
\hline \multirow{2}{*}{ Lokasi } & \multicolumn{3}{c}{ Suhu Rata-Rata $\left({ }^{\circ} \mathbf{C}\right)$} \\
\cline { 2 - 4 } & Pagi & Siang & Sore \\
\hline TPS Pasar Besar Kota Batu & 28 & 32 & 31 \\
TPS Pasar Krempyeng & 32 & 32 & 30 \\
TPS Pasar Lawang & 29 & 31 & 30 \\
TPS Pasar Niwen Bakalankrajan & 25,4 & 29,2 & 24,8 \\
\hline
\end{tabular}

Berdasarkan tabel 1 diatas, diketahui bahwa suhu rata-rata terendah sebesar $24,8^{\circ} \mathrm{C}$ pada pengukuran sore hari di TPS Pasar Niwen Bakalankrajan. Sedangkan suhu rata-rata tertinggi sebesar $32^{\circ} \mathrm{C}$ pada pengukuran pagi hari di TPS Pasar Krempyeng dan pada pengukuran siang hari di TPS Pasar Besar Kota Batu dan Pasar Krempyeng.

Hasil penelitian sebelumnya menunjukan suhu pada TPS pasar Motoling tertinggi pada waktu siang hari yaitu $31,8^{\circ} \mathrm{C}$ dan terendah pada waktu pagi yaitu $27,3^{\circ} \mathrm{C}$ dengan rata-rata suhu $29,1^{\circ} \mathrm{C}$. Pada saat yang sama didapatkan kepadatan lalat sore hari yaitu mencapai 25 ekor/blok grill terendah pada waktu pagi hari yaitu mencapai 12 ekor/blok grill dengan rata-rata 18 ekor/blok grill (Poluakan et al., 2016). Sedangkan penelitian Rahmadana \& Taha (2020) menunjukkan suhu udara pada TPS di Tempat Pelelangan Ikan sebesar $33^{\circ} \mathrm{C}$, dan pada saat yang sama didapatkan kepadatan lalat yang tinggi sebesar 10 ekor/blok grill. Kepadatan lalat di TPS tersebut sama tingginya dengan kepadatan pada Saluran Pembuangan Air Limbah (SPAL) sebesar 17 ekor/blok grill dengan suhu 40,3oC, dan kepadatan lalat di sarana air bersih sebesar 8 ekor/blok grill dengan suhu $32^{\circ} \mathrm{C}$. Namun, penelitian-penelitian tersebut tidak menjelaskan hubungan antara suhu dengan tingkat kepadatan lalat.

Suhu yang optimum akan mendukung perkembangbiakan lalat sejak dari fase telur hingga fase dewasa. Semakin tinggi suhu optimum maka semakin cepat perkembangan lalat. Suhu optimum untuk perkembangan lalat dari telur sampai dewasa terjadi pada suhu $28^{\circ} \mathrm{C}$. Sedangkan suhu yang diujicobakan untuk mendukung periode perkembangan terpanjang adalah $16^{\circ} \mathrm{C}$, yaitu 2 hari dari fase telur ke larva, 6 hari dari fase larva ke pupa, 7.5 hari dari fase pupa ke dewasa, sehingga dari fase telur menjadi dewasa diperlukan waktu selama 15.5 hari (Ihsan et al., 2016).

\subsection{Kelembaban}

Hasil pengukuran kelembaban yang dilakukan pada pagi, siang dan sore hari di Tempat Penampungan Sementara (TPS) sampah Pasar Besar Kota Batu, Pasar Krempyeng, Pasar Lawang, dan Pasar Niwen Bakalankrajan, disajikan pada tabel 2. 
Tabel 2. Kelembaban Rata-Rata di Tempat Penampungan Sementara (TPS)

\begin{tabular}{llll}
\hline \multirow{2}{*}{ Lokasi } & \multicolumn{3}{l}{ Kelembaban Rata-Rata (\%) } \\
\cline { 2 - 4 } & Pagi & Siang & Sore \\
\hline TPS Pasar Besar Kota Batu & 35 & 31 & 35 \\
TPS Pasar Krempyeng & 58 & 62 & 58 \\
TPS Pasar Lawang & 70 & 58 & 66 \\
TPS Pasar Niwen Bakalankrajan & 63,4 & 49,4 & 77 \\
\hline
\end{tabular}

Berdasarkan Tabel 2 di atas, diketahui bahwa kelembaban rata-rata terendah yakni sebesar 35\% pada pengukuran pagi dan sore hari di TPS Pasar Besar Kota Batu. Sedangkan kelembaban tertinggi sebesar $77 \%$ pada pengukuran sore hari di TPS Pasar Niwen Bakalankrajan.

Pengukuran kelembaban udara pada TPS di Pasar Motoling mendapatkan hasil kelembaban tertinggi pada pagi hari sebesar $68 \%$ dan terendah pada sore hari sebesar $60 \%$ dengan rata-rata kelembaban $61,6 \%$. Pada saat yang sama didapatkan kepadatan lalat tertinggi tertinggi pada waktu sore hari yaitu mencapai 25 ekor/blok grill terendah pada waktu pagi hari yaitu mencapai 12 ekor/blok grill dengan rata-rata 18 ekor/blok grill (Poluakan et al., 2016). Penelitian lainnya menemukan kelembaban udara di TPS tempat pelelangan ikan sebesar 64\%, dan pada saat yang sama didapatkan kepadatan lalat sebesar 10 ekor/blok grill (Rahmadana \& Taha, 2020). Sementara pada uji efektifitas light trap untuk menurunkan populasi lalat rumah didapatkan kelembaban yang bervariasi, mulai dari 45\% sampai dengan $64 \%$, dan pada saat yang sama didapatkan rata-rata kepadatan lalat yang tertangkap alat sebesar 3,04 ekor (Hilal, Gunawan, \& Firdaust, 2013).

Beberapa temuan penelitian tersebut di atas tidak menjelaskan lebih lanjut hubungan antara kelembaban dengan tingkat kepadatan lalat. Hasil penelitian Afrilia \& Wispriyono (2017) menyatakan bahwa meskipun tidak ada hubungan yang signifikan antara kepadatan kelembaban dengan kepadatan lalat, namun hasil uji statistik menunjukkan bahwa kelembaban yang optimum berisiko 2,2 kali memiliki kepadatan lalat di dalam rumah tinggi dibandingkan dengan kelembaban rumah yang tidak optimum. Maka dari itu, meskipun masih sedikit bukti yang menunjukan kelembaban berpengaruh terhadap kepadatan lalat, akan tetapi menjaga kondisi lingkungan agar tidak lembab tetap perlu dilakukan, setidaknya untuk menciptakan kondisi lingkungan yang sehat.

\subsection{Indeks Populasi Lalat}

Berdasarkan hasil pengamatan Indeks populasi lalat yang dilakukan pada pagi, siang dan sore hari di Tempat Penampungan Sementara (TPS) sampah Pasar Besar Kota Batu, Pasar Krempyeng, Pasar Lawang, dan Pasar Niwen Bakalankrajan, dapat disajikan pada tabel 3.

Tabel 3. Indeks Populasi Lalat di Tempat Penampungan Sementara (TPS)

\begin{tabular}{lccc}
\hline \multirow{2}{*}{ Lokasi } & \multicolumn{3}{c}{ Indeks Populasi Lalat } \\
\cline { 2 - 4 } & Pagi & Siang & Sore \\
\hline TPS Pasar Besar Kota Batu & 8,8 & 6,4 & 2,8 \\
TPS Pasar Krempyeng & 4,4 & 3,6 & 4,6 \\
TPS Pasar Lawang & 4,5 & 7,4 & 4,4 \\
TPS Pasar Niwen Bakalankrajan & 1,2 & 1,4 & 4,4 \\
\hline
\end{tabular}


Berdasarkan Tabel 3 di atas, diketahui bahwa indeks populasi lalat terendah sebesar 1,2 pada pengukuran pagi hari di TPS Pasar Niwen Bakalankrajan. Sedangkan indeks populasi lalat tertinggi sebesar 8,8 pada pengukuran pagi hari di TPS Pasar Besar Kota Batu.

Menurut Kementerian Kesehatan (2017), indeks populasi lalat merupakan angka populasi lalat di suatu lokasi dengan baku mutu sebesar $<2$. Sehingga apabila dilihat dari hasil penelitian ini, dapat disimpulkan bahwa indeks populasi lalat di sebagian besar TPS tidak memenuhi baku mutu vektor lalat yang disyaratkan oleh Kementerian Kesehatan. Hanya di TPS Pasar Niwen Bakalankrajan pada pengamatan pagi dan siang hari yang nilainya di bawah baku mutu vektor lalat yang disyaratkan yakni 1,2 (<2) dan 1,4 (<2).

Hasil penelitian ini sejalan dengan penelitian di Pasar Tradisional Kota Makassar yang menemukan rata-rata kepadatan lalat di sebagian besar pasar tersebut tidak memenuhi syarat baku mutu vektor lalat (Yunus \& Juherah, 2020). Hasil pengukuran kepadatan lalat di Tempat Penampungan Sementara (TPS) sampah Pasar Motoling, Minahasa Selatan juga mendapatkan kepadatan lalat yang tertinggi pada pengukuran sore hari sebesar 25 ekor/blok grill dan terendah pada waktu pagi hari yaitu mencapai 12 ekor/blok grill, dengan rata-rata 18 ekor/blok grill (Poluakan et al., 2016). Penelitian di Pasar Desa Adat Sembung menemukan dari 48 kali pengamatan, sebanyak 27 (56,3\%) kali pengamatan mendapatkan kepadatan lalat yang tinggi, dan sisanya mendapatkan kepadatan sedang (Ayu et al., 2020). Selain itu, penelitian di TPS tempat pelelangan ikan juga menemukan kepadatan lalat kategori padat dengan rata-rata kepadatan sebesar 10 ekor/blok grill (Rahmadana \& Taha, 2020).

Pedagang menjadi salah satu faktor yang turut mempengaruhi kepadatan lalat yang ada di pasar. Menurut Rahim et al., (2020), jumlah pedagang memiliki korelasi yang kuat dengan kepadatan lalat. Apabila jumlah pedagang meningkat, maka kepadatan lalat juga akan turut meningkat. Peningkatan jumlah pedagang memungkinkan keberadaan lalat di pasar karena meningkatnya jumlah sampah yang dihasilkan. Sampah yang tidak dikelola dengan baik akan mengundang keberadaan lalat. Hasil penelitian di Pasar Desa Adat Sembung menunjukkan bahwa $54,2 \%$ pedagang yang memiliki tingkat pengetahuan yang kurang baik dalam pengelolaan sampah memiliki kepadatan lalat yang tinggi. Pedagang yang memiliki sikap yang kurang baik dalam pengelolaan sampah yaitu $54,2 \%$ memiliki kepadatan lalat yang tinggi. Dan $56,3 \%$ pedagang yang memiliki tindakan yang kurang baik dalam pengelolaan sampah memiliki kepadatan lalat yang tinggi (Ayu et al., 2020).

Selain itu, salah satu faktor yang membuat indeks populasi lalat di TPS menjadi tinggi dikarenakan keberadaan timbulan sampah yang menarik lalat untuk hinggap dan berkembang biak di lokasi tersebut. Kondisi tempat sampah yang berisi banyak sampah organik akan mengundang lalat untuk mencari sumber makanan dan sekaligus berkembang biak (Masyhuda, Hertiningsih, \& Rahadian, 2017; Pituari, Dirhan, \& Murtiningsih, 2021). Semakin banyak timbulan sampah yang ada di penampungan sampah akan meningkatkan kepadatan lalat di tempat sampah tersebut. Hal tersebut ditegaskan oleh hasil penelitian Rahim, Rohmatunisa, \& Amalia (2020) yang menyatakan bahwa setiap penambahan $1 \%$ timbulan sampah, maka akan meningkatkan kepadatan lalat sebesar 17,971.

Pengelolaan tempat penampungan sampah di pasar menjadi sangat penting untuk menurunkan populasi lalat di pasar. Salah satu hal yang menyebabkan tingginya kepadatan 
lalat di pasar, selain kondisi lingkungan ialah pengelolaan sampah yang kurang efektif baik di dalam maupun di area sekitar pasar (Yunus \& Juherah, 2020). Lalat mampu berkembang biak pada tempat sampah meskipun tempat sampah memiliki penutup, juga dengan perilaku membuang sampah yang dapat mempengaruhi keberadaan lalat. Sampah harus dibuang minimal dua kali dalam seminggu, kemudian tempat sampah dibersihkan agar tidak tersisa sampah yang dapat mengundang lalat untuk berkembangbiak (Afrilia \& Wispriyono, 2017).

\subsection{Hubungan Suhu dengan Kepadatan Lalat}

Hasil analisis data tentang hubungan suhu rata-rata dengan indeks populasi lalat di Tempat Penampungan Sementara (TPS) sampah Pasar Besar Kota Batu, Pasar Krempyeng, Pasar Lawang, dan Pasar Niwen Bakalankrajan, dapat dilihat pada tabel 4:

Tabel 4. Hubungan Suhu Rata-Rata dengan Indeks Populasi Lalat

\begin{tabular}{clrrr}
\hline & & $\begin{array}{c}\text { Indeks Populasi } \\
\text { Lalat Pagi }\end{array}$ & $\begin{array}{c}\text { Indeks Populasi } \\
\text { Lalat Siang }\end{array}$ & $\begin{array}{c}\text { Indeks Populasi } \\
\text { Lalat Sore }\end{array}$ \\
\hline \multirow{2}{*}{ Suhu Rata- } & Pearson Correlation & .299 & .309 & .239 \\
Rata pagi & Sig (2-tailed) & .701 & .691 & .761 \\
& $N$ & 4 & 4 & 4 \\
Suhu Rata- & Pearson Correlation & .817 & .606 & -.400 \\
Rata Siang & Sig (2-tailed) & .183 & .394 & .600 \\
Suhu Rata- & Pearson Correlation & 4 & 4 & 4 \\
Rata Sore & Sig (2-tailed) & .853 & .822 & -.453 \\
& $N$ & .178 & .178 & .565 \\
& & 4 & 4 & 4 \\
\hline
\end{tabular}

${ }^{*}$ Correlation is significant at the 0.05 level (2-tailed)

Hasil uji statistik dengan tingkat kepercayaan 95\% diyakini bahwa pada waktu pagi, siang, maupun sore hari tidak terdapat korelasi antara suhu rata-rata dengan Indeks Populasi Lalat berpedoman pada nilai sig yang semuanya $>0,05$ tersaji pada tabel diatas.

Hasil penelitian ini, sejalan dengan hasil pengamatan kepadatan lalat pada rumahrumah di sekitar Tempat Pembuangan Akhir (TPA) sampah, yang menunjukkan bahwa tidak terdapat hubungan yang signifikan antara suhu dengan kepadatan lalat di dalam maupun di luar rumah. Namun, suhu yang optimum berisiko 2,2 kali memiliki kepadatan lalat di luar rumah yang lebih tinggi dibandingkan dengan suhu di luar rumah yang tidak optimum (Afrilia \& Wispriyono, 2017). Sedangkan hasil temuan berbeda dikemukakan oleh Ramadhani, Hestiningsih, \& Kusariana, (2019), yang menemukan ada hubungan yang signifikan antara suhu dengan kepadatan lalat di rumah-rumah penduduk Desa Purwodadi.

Meskipun hasil penelitian ini tidak menunjukan korelasi antara suhu rata-rata dengan populasi lalat, akan tetapi berbagai literatur menyatakan bahwa lalat membutuhkan suhu yang optimum di setiap fase kehidupannya. Suhu sangat berpengaruh terhadap daya tetas telur menjadi larva dengan suhu optimum sebesar $29^{\circ} \mathrm{C}$, sedangkan suhu terendah dan tertinggi untuk mendukung daya tetas telur sebesar $12^{\circ} \mathrm{C}$ dan $47^{\circ} \mathrm{C}$. Persentase daya tahan larva menjadi pupa tertinggi pada suhu $27^{\circ} \mathrm{C}(84 \%)$, sedangkan persentase terendah terjadi pada suhu $39^{\circ} \mathrm{C}$ (25\%). Persentase daya tahan pupa menjadi lalat dewasa terendah terjadi pada suhu $16^{\circ} \mathrm{C}$ (46.2\%), sedangkan persentase tertinggi terjadi pada suhu $39^{\circ} \mathrm{C}(75 \%)$ (Ihsan et al., 2016). 
Selain itu juga, kondisi di iklim di suatu daerah juga dapat mempengaruhi tahap perkembangbiakan lalat. Pada kondisi iklim yang hangat, lalat rumah menyelesaikan siklus hidupnya dari 2-3 minggu. Ini menghasilkan populasi besar dengan kecepatan tinggi karena jumlah banyaknya produksi telur yang besar dengan tingkat perkembangan yang tinggi. Sedangkan di daerah dengan iklim sedang, lalat dapat menghasilkan 10-12 generasi dalam setahun. Namun sebaliknya, mereka hanya dapat menghasilkan 4-6 generasi di daerah dingin, di mana perkembangbiakannya terbatas pada bulan-bulan hangat (Iqbal et al., 2014).

\subsection{Hubungan Kelembaban dengan Kepadatan Lalat}

Hasil uji analisis data tentang hubungan kelembaban rata-rata dengan indeks populasi lalat di Tempat Penampungan Sementara (TPS) sampah Pasar Besar Kota Batu, Pasar Krempyeng, Pasar Lawang, dan Pasar Niwen Bakalankrajan, dapat dilihat pada tabel 5.

Tabel 5. Hubungan Kelembaban Rata-Rata dengan Indeks Populasi Lalat

\begin{tabular}{clrrr}
\hline & & $\begin{array}{c}\text { Indeks Populasi } \\
\text { Lalat Pagi }\end{array}$ & $\begin{array}{c}\text { Indeks Populasi } \\
\text { Lalat Siang }\end{array}$ & $\begin{array}{c}\text { Indeks Populasi } \\
\text { Lalat Sore }\end{array}$ \\
\hline Kelembaban & Pearson Correlation & -.811 & -.197 & -.910 \\
Rata-Rata & Sig (2-tailed) & .189 & .803 & .090 \\
pagi & $N$ & 4 & 4 & 4 \\
Kelembaban & Pearson Correlation & -.628 & -.195 & $.950^{*}$ \\
Rata-Rata & Sig (2-tailed) & .372 & .805 & .050 \\
Siang & $N$ & 4 & 4 & 4 \\
Kelembaban & Pearson Correlation & $-.976^{*}$ & -.551 & .853 \\
Rata-Rata & Sig (2-tailed) & .024 & .449 & .147 \\
Sore & $N$ & 4 & 4 & 4 \\
\hline
\end{tabular}

${ }^{*}$ Correlation is significant at the 0.05 level (2-tailed)

Dengan tingkat kepercayaan 95\% diyakini bahwa terdapat korelasi antara kelembaban rata-rata pada waktu sore hari dengan Indeks Populasi Lalat pada waktu pagi hari berpedoman pada nilai sig sebesar $0.024(<0,05)$ tersaji pada tabel diatas. Hubungan korelasi diantara keduanya adalah bersifat negatif kuat.

Hasil ini berbeda dengan hasil penelitian sebelumnya yang menunjukkan menunjukkan bahwa tidak terdapat hubungan yang signifikan antara kelembaban dengan kepadatan lalat di dalam maupun di luar rumah di sekitar Tempat Pembuangan Akhir (TPA) sampah (Afrilia \& Wispriyono, 2017). Pengukuran kepadatan lalat di rumah penduduk Desa Purwodadi menemukan tidak ada hubungan yang signifikan antara kelembaban udara dengan kepadatan lalat (Ramadhani et al., 2019). Penelitian lainya juga menunjukan bahwa kelembaban udara tidak mempengaruhi kehidupan lalat sehingga dapat terbang ke kandang sapi (Ardi, Triyantoro, \& Widiyanto, 2021).

Menariknya, hasil penelitian ini menunjukan bahwa terdapat korelasi antara kelembaban udara pada waktu sore hari dengan indeks populasi lalat pada waktu siang hari. Namun, tidak terdapat korelasi antara kelembaban pada waktu pagi hari dengan indeks populasi lalat pada waktu siang hari dan kelembaban udara pada waktu pagi hari dengan indeks populasi lalat pada waktu sore hari. Hal tersebut kemungkinan diakibatkan oleh tidak adanya paparan sinar matahari pada sore hari hingga pagi hari menyebabkan kelembaban udara terjaga sehingga memungkinkan lalat untuk hidup. Kondisi berbeda terjadi dari pagi hingga sore hari, yang mana terdapat paparan sinar matahari di TPS sehingga berpengaruh 
pada kelembaban udara. Kelembaban yang optimum untuk perkembangbiakan berisiko 2,2 kali memiliki kepadatan lalat yang tinggi di dalam rumah dibandingkan dengan kelembaban rumah yang tidak optimum (Afrilia \& Wispriyono, 2017)

Indeks populasi lalat yang tinggi di Tempat Penampungan Sementara (TPS) sampah pasar dikhawatirkan akan menjadi masalah kesehatan masyarakat di kemudian hari. Menurut Iqbal et al., (2014), lalat dapat berperan sebagai penular berbagai penyakit pada manusia, antara lain tipus, disentri, difteri, kusta, TBC dan parasit usus. Studi literatur yang dilakukan oleh Andiarsa (2018), menyatakan bahwa lalat merupakan vektor mekanik untuk penyakit seperti diare, myasis, kecacingan dan antraks. Lebih lanjut dijelaskan bahwa beberapa surveilans lalat secara intensif dan rutin menemukan keterkaitan antara meningkatnya populasi lalat pada suatu masa dengan munculnya kejadian luar biasa kasus foodborne disease. Masalah kesehatan tersebut diakibatkan karena lalat memiliki kemampuan mengambil berbagai patogen dari sampah, limbah dan berbagai sumber kotoran lainnya, yang kemudian dipindahkan melalui mulut, muntahan, feses, serta tubuh yang telah terkontaminasi ke makanan manusia (Sanchez-Arroyo \& Capinera, 2013).

Menurut Khamesipour et al., (2018) mikroorganisme yang terbukti mampu dibawa oleh lalat seperti Ascaris spp. Entamoeba spp., cacing tambang, Trichuris spp., Penicillium spp., Aspergillus spp., dan Candida spp.. Hasil identifikasi lalat yang ditangkap di pasar Surabaya menemukan bakteri E. coli, Salmonella, dan Staphylococcus, serta Shigella spp di tubuh lalat (Safitri, Hastutiek, \& Arimbi, 2017). Hal ini kemudian dipertegas oleh hasil identifikasi bakteri di Tempat Pembuangan Akhir (TPA) sampah dan pasar yang menemukan bakteri genus Salmonella, Providencia, Escherichia dan Vibrio pada lalat yang berasal dari TPA, serta bakteri genus Salmonella dan Proteus pada lalat yang berasal dari pasar (Putri, 2018).

Dengan berbagai bukti masalah kesehatan masyarakat yang mungkin terjadi, vektor lalat seharusnya tidak bisa diabaikan. Sejauh ini, transmisi mekanis patogen yang diakibatkan oleh serangga seperti lalat sering diabaikan karena terlalu mementingkan penyakit yang ditularkan secara biologis seperti malaria, demam kuning, dan lain sebagainya (Khamesipour et al., 2018). Di Indonesia, program dan dukungan terhadap pengendalian lalat masih sangat minim dilakukan. Hal ini terbukti dengan dukungan anggaran kegiatan yang minim dari pemerintah untuk vektor diare (lalat) dibandingkan dengan dengan vektor lainnya. Hal ini menyebabkan program menjadi kurang leluasa karena harus mempertimbangkan kegiatan lain yang harus diprioritaskan (Andiarsa, 2018). Dengan dukungan dana dan program yang minim, maka pengendalian yang mungkin dan murah untuk dilakukan ialah menyadarkan masyarakat untuk menerapkan Perilaku Hidup Bersih dan Sehat (PHBS), serta menjaga sanitasi lingkungan. Penerapan PHBS dan menjaga sanitasi merupakan langkah awal untuk mencegah keberadaan lalat yang dapat membahayakan kesehatan masyarakat.

\section{Simpulan}

Suhu rata-rata terendah sebesar $24,8^{\circ} \mathrm{C}$ pada pengukuran sore hari di TPS Pasar Niwen Bakalankrajan. Sedangkan suhu rata-rata tertinggi sebesar $32^{\circ} \mathrm{C}$ pada pengukuran pagi hari di TPS Pasar Krempyeng dan pada pengukuran siang hari di TPS Pasar Besar Kota Batu dan Pasar Krempyeng. Kelembaban rata-rata terendah yakni sebesar 35\% pada pengukuran pagi dan sore hari di TPS Pasar Besar Kota Batu. Sedangkan kelembaban tertinggi sebesar 77\% pada pengukuran sore hari di TPS Pasar Niwen Bakalankrajan. Indeks populasi lalat terendah sebesar 1,2 pada pengukuran pagi hari di TPS Pasar Niwen Bakalankrajan. Sedangkan indeks 
populasi lalat tertinggi sebesar 8,8 pada pengukuran pagi hari di TPS Pasar Besar Kota Batu. Hasil uji statistik dengan tingkat kepercayaan 95\% diyakini bahwa pada waktu pagi, siang, maupun sore hari tidak terdapat korelasi antara suhu rata-rata dengan Indeks Populasi Lalat berpedoman pada nilai sig yang semuanya $>0,5$. Hasil uji statistik dengan tingkat kepercayaan 95\% diyakini bahwa terdapat korelasi antara kelembaban rata-rata pada waktu sore hari dengan Indeks Populasi Lalat pada waktu pagi hari berpedoman pada nilai sig sebesar 0.024 $(<0,5)$. Hubungan korelasi diantara keduanya adalah bersifat negatif kuat.

\section{Daftar Rujukan}

Afrilia, E. N., \& Wispriyono, B. (2017). Hubungan Kondisi Rumah dan Kepadatan Lalat di Sekitar Tempat Pembuangan Akhir Sampah. Kes Mas: Jurnal Fakultas Kesehatan Masyarakat, 11(2), 99-104. https://doi.org/10.12928/kesmas.v11i2.5810

Andiarsa, D. (2018). Lalat: Vektor yang Terabaikan Program? Balaba: Jurnal Litbang Pengendalian Penyakit Bersumber Binatang Banjarnegara, 14(2), 201-214. https://doi.org/10.22435/blb.v14i2.67

Ardi, A. G. N., Triyantoro, B., \& Widiyanto, T. (2021). Hubungan Sanitasi Kandang dengan Kepadatan Lalat di Kecamatan Sokaraja. Buletin KeslingMas, 40(1), 22-26. Retrieved from http://ejournal.poltekkessmg.ac.id/ojs/index.php/keslingmas/article/view/5210

Ayu, P. M., Sali, I. W., \& Aryana, I. K. (2020). Hubungan Tingkat Pengetahuan, Sikap dan Tindakan Pedagang dalam Mengelola Sampah dengan Kepadatan Lalat di Pasar Desa Adat Sembung Tahun 2020. Jurnal Kesehatan Lingkungan, 10(2), 108-115. Retrieved from https://ejournal.poltekkesdenpasar.ac.id/index.php/JKL/article/view/1267

Hilal, N., Gunawan, A. T., \& Firdaust, M. (2013). Efektifitas Light Trap dalam Menurunkan Populasi Lalat Rumah (Musca Domestica). Link, 9(1), 458-465. Retrieved from http://ejournal.poltekkessmg.ac.id/ojs/index.php/link/article/download/165/123

Ihsan, I. M., Hidayati, R., \& Hadi, U. K. (2016). Pengaruh Suhu Udara terhadap Fekunditas dan Perkembangan Pradewasa Lalat Rumah (Musca Domestica). Jurnal Teknologi Lingkungan, 17(2), 100-107. https://doi.org/https://doi.org/10.29122/jtl.v17i2.1044

Iqbal, W., Malik, M. F., Sarwar, M. K., Azam, I., Iram, N., \& Rashda, A. (2014). Role of Housefly (Musca domestica, Diptera; Muscidae) as A Disease Vector; A Review. Journal of Entomology and Zoology Studies, 2(2), 159163. Retrieved from https://www.researchgate.net/publication/275100264

Kementerian Kesehatan. Peraturan Menteri Kesehatan Republik Indonesia Nomor 50 Tahun 2017 tentang Standar Baku Mutu Kesehatan Lingkungan dan Persyaratan Kesehatan untuk Vektor dan Binatang Pembawa Penyakit serta Pengendaliannya., Pub. L. No. Nomor 50 Tahun 2017, 1 (2017).

Khamesipour, F., Lankarani, K. B., Honarvar, B., \& Kwenti, T. E. (2018). A Systematic Review of Human Pathogens Carried by the Housefly (Musca domestica L.). BMC Public Health, 18(1049), 1-15. https://doi.org/10.1186/s12889-018-5934-3

Masyhuda, M., Hertiningsih, R., \& Rahadian, R. (2017). Survei Kepadatan Lalat di Tempat Pembuangan Akhir (TPA) Sampah Jatibarang Tahun 2017. Jurnal Kesehatan Masyarakat (e-Journal), 5(4), 560-569. Retrieved from https://ejournal3.undip.ac.id/index.php/jkm/article/view/18714

Pituari, P., Dirhan, D., \& Murtiningsih, M. (2021). Analisis Tingkat Kepadatan Lalat di Tempat Pembuangan Akhir (TPS) Sampah Air Sebakul Kota Bengkulu. Jurnal Sains Kesehatan, 27(3), 9-17. Retrieved from http://jurnal.stikestrimandirisakti.ac.id/index.php/jsk/article/view/127/pdf

Poluakan, M., Rumajar, P. D., \& Pakasi, F. G. (2016). Tingkat Kepadatan Lalat di Pasar Motoling Kecamatan Motoling Kabupaten Minahasa Selatan. Jurnal Kesehatan Lingkungan, 6(1), 28-35. Retrieved from https://ejurnal.poltekkes-manado.ac.id/index.php/jkl/article/view/608/547

Putri, Y. P. (2018). Identifikasi Bakteri pada Tubuh Lalat Rumah (Musca domestica Linn.) di Tempat Pembuangan Akhir Sampah (TPA) dan Pasar. Jurnal Biota, 4(1), 29-35. https://doi.org/10.19109/biota.v4i1.1626

Rahim, F. K., Rohmatunisa, R., \& Amalia, I. S. (2020). Model Prediksi Kepadatan Lalat di Pasar Kabupaten Kuningan Jawa Barat Indonesia. Journal of Public Health Innovation, 10(1), 72-82. Retrieved from https://ejournal.stikku.ac.id/index.php/jphi/article/view/208

Rahmadana, S., \& Taha, L. (2020). Studi Sanitasi Lingkungan dengan Kepadatan Lalat pada Pelelangan Ikan Beba di Desa Tamasaju Kecamatan Galesong Utara Kabupaten Takalar. Jurnal Sulolipu: Media 
Sport Science and Health, 3(6), 2021, 429-439

Komunikasi Sivitas Akademika Dan Masyarakat, 20(1), $17 . \quad$ Retrieved from http://www.journal.poltekkes-mks.ac.id/ojs2/index.php/Sulolipu/article/view/1458/1112

Ramadhani, C., Hestiningsih, R., \& Kusariana, N. (2019). Faktor-Faktor yang Berhubungan dengan Kepadatan Lalat di Desa Purwodadi Kecamatan Margoyoso Kabupaten Pati. Jurnal Kesehatan Masyarakat (eJournal), 7(3), 29-38.

Safitri, V., Hastutiek, P., \& Arimbi, A. (2017). Indentifikasi Bakteri pada Eksoskeleton Lalat di Beberapa Pasar di Surabaya. Journal of Parasite Science, 1(1), 1. https://doi.org/10.20473/jops.v1i1.16232

Sanchez-Arroyo, H., \& Capinera, J. L. (2013). House fly, Musca domestica Linnaeus (Insecta: Diptera: Muscidae). IFA Extension, University of Florida, 28, 124-230. Retrieved from https://edis.ifas.ufl.edu/pdf/IN/IN20500.pdf

Yunus, H., \& Juherah, J. (2020). Gambaran Penangan Sampah dengan Tingkat Kepadatan Lalat di Pasar Tradisional di Kota Makassar. Jurnal Sulolipu, 20(1), 66-75. https://doi.org/10.32382/sulolipu.v20i1.1478 